\title{
Ice-Nucleating Active Bacteria Reduce the Cold-Hardiness of the Freeze-Intolerant Colorado Potato Beetle (Coleoptera: Chrysomelidae)
}

\author{
RICHARD E. LEE, JR., ${ }^{1}$ JON P. COSTANZO, ${ }^{2}$ PHILLIP E. KAUFMAN, ${ }^{3}$ MARCIA R. LEE, 4 \\ AND JEFFREY A. WYMAN ${ }^{3}$
}

Department of Zoology and Department of Microbiology, Miami University, Oxford, $\mathrm{OH} 45056$

\begin{abstract}
J. Econ. Entomol. 87(2): 377-381 (1994)
ABSTRACT In laboratory experiments, a freeze-dried concentrated form of the icenucleating active bacteria, Pseudomonas syringae, was used to decrease the supercooling capacity of field-collected diapausing Colorado potato beetles, Leptinotarsa decemlineata (Say). Application of the $P$. syringae to adult beetles increased their mean supercooling point values from $-7.6 \pm 0.2^{\circ} \mathrm{C}$ (untreated) to $-3.7 \pm 0.1^{\circ} \mathrm{C}(1,000 \mathrm{ppm})$. No beetles survived cooling to temperatures below their supercooling point, indicating that this species is freeze-intolerant. During tests conducted in 1991 and 1992, the increase in the supercooling point was directly dependent on the amount of $P$. syringae added to soil containing the beetles. Cumulative freezing distributions indicated that $80 \%$ of beetles treated with $100 \mathrm{ppm}$ of $P$. syringae would be expected to freeze and die when exposed to $-5^{\circ} \mathrm{C}$; in contrast, none or very few of the untreated control beetles would be expected to freeze at this temperature. Other experiments demonstrated that the capacity of $P$. syringae treatments to increase the supercooling point of the beetles decreased after $2 \mathrm{wk}$ of exposure at $4^{\circ} \mathrm{C}$ and when experiments were done at $10^{\circ} \mathrm{C}$. If delivery systems were developed that would expose adult beetles to ice nucleating agents and preserve their ice nucleating activity until critical low-temperature exposure occurs in mid-winter, these nucleating agents could be used in conjunction with cultural control strategies for increasing winter mortality.
\end{abstract}

KEY WORDS Leptinotarsa decemlineata, cold-hardiness, ice nucleating bacteria

The Colorado potato beetle, Leptinotarsa decemlineata (Say), is the most serious defoliating pest of potatoes, Solanum tuberosum L., in North America. Its status as a serious pest has evolved largely as a consequence of its development of insecticide resistance and the current practice of planting extensive potato monocultures that promote the cumulative build up of Colorado potato beetle populations from year-toyear (Casagrande 1987, Ioannidis et al. 1991). Consequently, efforts to control this pest have focused increasingly on alternative approaches.

One control strategy relies on cultural methods to rapidly expose beetles to lethal subzero temperatures during the winter (Kung et al. 1992, Milner et al. 1992). Specifically, adults are induced to aggregate outside normal overwinter-

\footnotetext{
I To whom reprint requests should be addressed at: Department of Zoology, Miami University, Oxford, OH 45056

2 Department of Zoology, Miami University, Oxford, OH 45056.

${ }^{3}$ Department of Entomology, University of Wisconsin-Madison, Madison, WI 53706

+ Department of Microbiology, Miami University, Oxford, OH 45056 .
}

ing sites by planting trap crops late in the growing season on the edges of fields. Mulching these areas would encourage beetles to remain at the site of the trap crop to overwinter and may also reduce the depth to which the beetles burrow during the winter. Overwintering mortality of the beetles then can be increased when the mulch is removed in midwinter (Milner et al. 1992).

The supercooling point refers to the temperature at which ice nucleation occurs spontaneously within an insect (Lee 1991). For freezeintolerant insects this value represents the absolute lower lethal temperature for survival. Many freeze-intolerant species seasonally depress their supercooling points, thereby increasing their cold-hardiness in preparation for winter. Previous studies have demonstrated that the supercooling point of cold-hardy but freezeintolerant species may be increased by the application of ice-nucleating active bacteria (Fields 1990, 1992; Lee et al. 1991, 1992, 1993; Strong-Gunderson et al. 1990). Consequently, these bacteria may offer a novel means for the biological control of overwintering insects 
(Fields 1990, 1992; Lee 1991; Lee et al. 1993; Strong-Gunderson et al. 1990).

Our primary objective in this study was to determine whether ice-nucleating active bacteria could be used to elevate the supercooling point of diapausing adults of the Colorado potato beetle. We determined the effect of various concentrations of Pseudomonas syringae and the duration of its exposure on the supercooling point of beetles. To simulate overwintering conditions, we exposed beetles to ice-nucleating active bacteria mixed with soil. Our ultimate goal is to determine whether ice-nucleating active bacteria can be used in combination with the cultural control methods of Milner et al. (1992) to increase the susceptibility of overwintering populations of the Colorado potato beetle to low temperature.

\section{Materials and Methods}

Experimental Animals. Because our objective was to test Colorado potato beetles that had prepared naturally for overwintering, collections were made from fields in which the potato vines had been killed in preparation for harvesting in late August and early September from the Hancock Agricultural Station in central Wisconsin and shipped to Miami University by overnight carrier. When potato vines are killed, beetles normally leave the fields and search for suitable overwintering sites. When received at Miami University, beetles were held unfed at $15^{\circ} \mathrm{C}$, $10: 14$ (L:D) h for 1-2 wk before they were separated into groups $(n=25-50)$, placed in plastic cups containing $200 \mathrm{~g}$ sand moistened with $15 \mathrm{ml}$ water, and held in the dark at $4^{\circ} \mathrm{C}$. Because under these conditions the beetles readily burrowed into the sand, we assumed that they were in the expected physiological state typical of overwintering individuals.

Ice-Nucleating Active Bacteria. Ice-nucleating active bacteria were formulated as a concentrated, freeze-dried, and killed preparation of Pseudomonas syringae provided by Genencor International, Rochester, NY. The P. syringae used in this study had an ice-nucleating activity of $2.02 \times 10^{4}$ ice-nucleating sites per gram.

The beetles were exposed to the bacterial preparation by thoroughly mixing it into moist sand to which beetles were subsequently introduced. Beetles were permitted to move about freely over this substrate for $48 \mathrm{~h}$ before we determined their supercooling points.

Supercooling Point Determination. Supercooling points were determined by positioning beetles in contact with a 30-gauge copper-constantan thermocouple inside a $1.5-\mathrm{ml}$ polyethylene tube. The tubes were placed inside glass test tubes suspended in a refrigerated bath $\left(5^{\circ} \mathrm{C}\right)$ and allowed to thermoequilibrate for $5 \mathrm{~min}$ before being cooled at $\approx 0.6^{\circ} \mathrm{C} \mathrm{min}{ }^{-1}$. The lowest temper- ature attained before the release of the latent heat of crystallization, caused by the formation of ice in body fluids, was recorded as the supercooling point.

Experimental Design. Three sets of experiments were conducted. The first set established whether the inert carrier portion for the dry, powdered $P$. syringae preparation had an effect on the supercooling point of $L$. decemlineata. The test involved running 2-4 replicates of $n=$ 11 to 12 beetles in each of the following treatment groups: control (no additive), 100 ppm of carrier (ice-nucleating product lacking the $P$. syringae fraction), and $100 \mathrm{ppm}$ of $P$. syringae in carrier.

In a second set of experiments, the dosesupercooling point relationship was determined for the P. syringae preparation in 1991 and 1992. These experiments involved 4-5 replicates of $n=9$ to 12 beetles in each of the following treatment groups: control (no additive), 1, 10, 100 , and 1,000 ppm P. syringae. The concentration of 1 ppm was tested only in 1992.

The third set of experiments examined factors related to the potential loss of ice-nucleation activity. First, the supercooling points of beetles were determined $1,3,7,14$, or $21 \mathrm{~d}$ after initial exposure to $0 \mathrm{ppm}$ (control), $100 \mathrm{ppm}$, or 1,000 ppm ice-nucleating product. The beetles remained in contact with the treated substrate and were exposed to $4^{\circ} \mathrm{C}$ until they were tested. Testing was done using duplicate samples, except on day 21 , in which case sufficient animals were available for only one test. For each treatment group, the reported mean supercooling point at each time interval was based on a total sample of $n=8$ to 17 beetles.

The influence of incubation temperature on the effect of treatment with $P$. syringae was studied by comparing the supercooling points of beetles determined on the 7th day of their exposure to $0 \mathrm{ppm}$ (control), $100 \mathrm{ppm}$, or $1,000 \mathrm{ppm}$ $P$. syringae at $4^{\circ} \mathrm{C}$ against values from a separate set of beetles treated similarly but exposed to $10^{\circ} \mathrm{C}$.

Supercooling point values were compared among groups using either one-factor or twofactor analysis of variance (ANOVA), with means distinguished $(P<0.05)$ using the least significant difference test (Snedecor \& Cochran 1982).

\section{Results and Discussion}

Carrier Tests. Because the mean supercooling point of beetles treated with 100 ppm carrier was not statistically different than that of untreated beetles, we judged that the carrier used in the commercial preparation lacks nucleating activity (Table 1). In marked contrast, beetles treated with ice-nucleating product had a mean supercooling point that was 3.4 and $3.9^{\circ} \mathrm{C}$ higher $(F=65.3 ; \mathrm{df}=2,91 ; P<0.001)$ relative to 
Table 1. Supercooling points $\left({ }^{\circ} \mathrm{C}\right)$ of Colorado potato beetles incubated in sand (untreated) or sand containing 100 ppm of bacterial carrier or $P$. syringae

\begin{tabular}{lcc}
\hline \hline Treatment & $n$ & Mean \pm SEM \\
\hline Untreated & 46 & $-7.5 \mathrm{a} \pm 0.34$ \\
Carrier & 23 & $-8.0 \mathrm{a} \pm 0.36$ \\
$P$. syringae & 23 & $-4.1 \mathrm{~b} \pm 0.26$ \\
\hline
\end{tabular}

Within a column, means followed by the same letter are not significantly different $(P>0.05$; Fisher's least significant differences test).

untreated and carrier-treated beetles, respectively. These results attest to the fact that icenucleating activity was attributable to the $P$. syringae preparation. The fact that no beetles survived cooling to temperatures below their supercooling point indicates that this species is freeze-intolerant.

Dose-Supercooling Point Relationship. Mean supercooling points of beetles treated with $P$. syringae in concentrations ranging from 0 to 1,000 ppm were determined for populations sampled in both 1991 and 1992 (Table 2). In 1991, the means of $n=10$ to 11 beetles ranged from $-6.4 \pm 0.3^{\circ} \mathrm{C}$ (untreated) to $-2.8 \pm 0.2^{\circ} \mathrm{C}(1,000 \mathrm{ppm})$ and differed significantly $(F=43.7 ; \mathrm{df}=3,42 ; P<0.001)$ among the treatment groups. Similarly, in 1992 the supercooling point means $(n=44$ to 58 ) increased when beetles were exposed to increasing concentrations of $P$. syringae, ranging from $-7.6 \pm 0.2^{\circ} \mathrm{C}$ (untreated) to $-3.7 \pm 0.1^{\circ} \mathrm{C}(1,000$ $\mathrm{ppm})$, and differed significantly $(F=62.4 ; \mathrm{df}=4$, $240 ; P<0.001)$ among the treatment groups. In these 1992 tests, a dose of 1 ppm resulted in a supercooling point that was statistically higher than that of the untreated control. However, the supercooling points of beetles treated with 1 ppm and $10 \mathrm{ppm}$ could not be distinguished statistically. Additionally, doses of $100 \mathrm{ppm}$ and $1,000 \mathrm{ppm}$, which were significantly more effective than doses of 1 and $10 \mathrm{ppm}$, resulted in sta-

Table 2. Effect of $P$. syringae on the supercooling point of diapausing adults of the Colorado potato beetle (shown \pm 1 SEM)

\begin{tabular}{rcc}
\hline \hline Concentration & $n$ & Mean \pm SEM \\
\hline & 1991 & \\
0 & 11 & $-6.4 \pm 0.3 \mathrm{a}$ \\
1 & 0 & - \\
10 & 11 & $-3.8 \pm 0.3 \mathrm{~b}$ \\
100 & 10 & $-2.8 \pm 0.2 \mathrm{c}$ \\
1,000 & 11 & \\
& 1992 & $-7.6 \pm 0.2 \mathrm{a}$ \\
0 & 58 & $-5.9 \pm 0.3 \mathrm{~b}$ \\
1 & 44 & $-6.3 \pm 0.2 \mathrm{~b}$ \\
10 & 46 & $-4.2 \pm 0.2 \mathrm{c}$ \\
100 & 45 & $-3.7 \pm 0.1 \mathrm{c}$ \\
1,000 & 58 &
\end{tabular}

Means followed by the same letter are not significantly different $(P>0.05$; Fisher's least significant differences test).

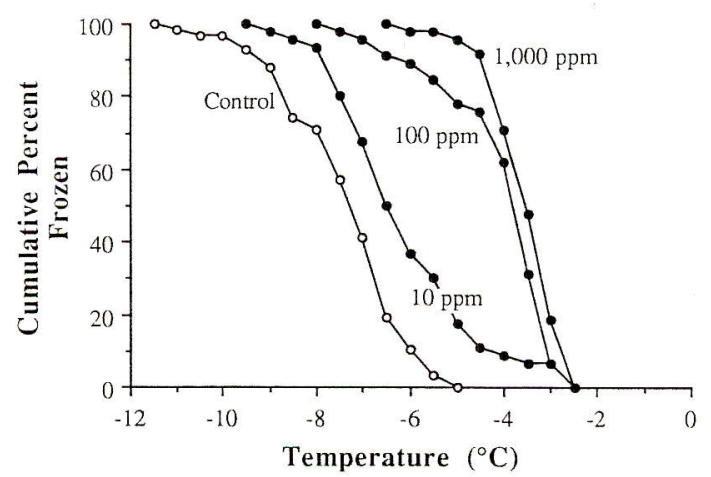

Fig. 1. Cumulative freezing profile based on individual supercooling points for Colorado potato beetles exposed to various concentrations of $P$. syringae in soil for $48 \mathrm{~h}$ at $4^{\circ} \mathrm{C}$.

tistically indistinguishable supercooling points in both 1991 and 1992. These results suggest that the effect of $P$. syringae on the supercooling point elevation is dose-dependent, effective even at very low concentrations (e.g., 1 ppm), and most effective at concentrations of $\leq 100 \mathrm{ppm}$.

Cumulative freezing distributions based on individual supercooling point values were determined only for beetles used in the 1992 tests because sample sizes were substantially larger in this year (Fig. 1). These curves are useful because they show a profile of the theoretical, absolute lower lethal temperature for a population of beetles treated with various concentrations of $P$. syringae. For example, if beetles were exposed to $-5^{\circ} \mathrm{C}, 80 \%$ of those treated with 100 ppm of $P$. syringae would be expected to freeze and die; in contrast, none or very few of the untreated control beetles would be expected to freeze at this temperature. In addition, the similarity of the 100 and 1,000 ppm curves further suggests that maximal effectiveness is achieved with $100 \mathrm{ppm}$.

Temporal and Thermal Aspects of Treatment with Pseudomonas Syringae. Analyses involving two-factor ANOVAs (incubation time versus $P$. syringae concentration) showed that mean supercooling point depended significantly on both incubation time $(F=8.3 ; \mathrm{df}=4,209 ; P<0.001)$ and bacterial concentration $(F=41.2 ; \mathrm{df}=2$, $209 ; P<0.001)$. The highly significant $(F=6.0$; $\mathrm{df}=8,209 ; P<0.001)$ interaction term indicated that the dose-response relationship varied markedly over time (Fig. 2). Mean supercooling points were significantly $(P<0.05)$ higher in 100 ppm $P$. syringae and $1,000 \mathrm{ppm} P$. syringae groups relative to untreated controls on days 1,3 , and 7 , but not on days 14 and 21 . Therefore, the nucleation activity of the bacterial preparation had been lost $\leq 2 \mathrm{wk}$ after application at $4^{\circ} \mathrm{C}$.

Analyses involving two-factor ANOVAs (temperature versus bacterial concentration) showed that the mean supercooling point measured $7 \mathrm{~d}$ 


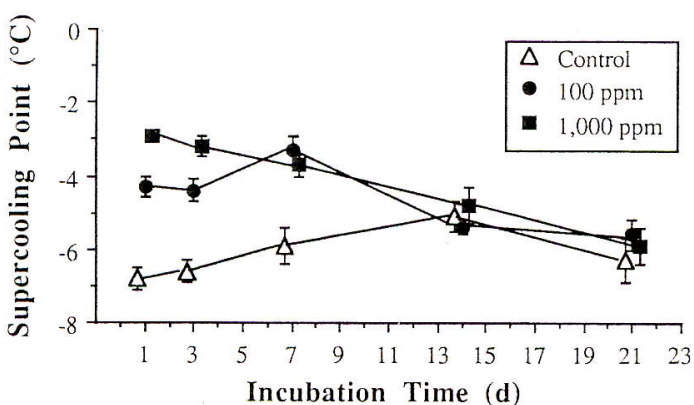

Fig. 2. Effect of the duration of exposure to P. syringae on the supercooling point of diapausing adults $(n=8-17)$ of the Colorado potato beetle. Beetles were exposed to 100 or $1,000 \mathrm{ppm} P$. syringae for up to $21 \mathrm{~d}$ at $4^{\circ} \mathrm{C}$.

after treatment was influenced significantly by both incubation temperature $(F=6.7 ; \mathrm{df}=1,86$; $P=0.012)$ and $P$. syringae concentration $(F=$ 8.9; $\mathrm{df}=2,86 ; P<0.001)$. The highly significant $(F=7.4 ; \mathrm{df}=2,86 ; P=0.001)$ interaction term revealed that the dose-response relationship differed between the $4^{\circ}$ and $10^{\circ} \mathrm{C}$ incubation groups (Table 3). Means for untreated beetles held at $4^{\circ}$ and $10^{\circ} \mathrm{C}$ were similar. Conversely, beetles treated with 100 ppm $P$. syringae had significantly $(P<0.05)$ higher supercooling points after incubation at $4^{\circ}$ than $10^{\circ} \mathrm{C}$, although this trend was not significant with beetles treated with $1,000 \mathrm{ppm} P$. syringae. These results suggest that ice-nucleating activity was better retained during incubation at the lower temperature. Previous studies have reported a loss of activity with time at temperatures above $0^{\circ} \mathrm{C}$ (Lee et al. 1993).

The ice-nucleating activity of $P$. syringae used in these studies was sufficient at concentrations of $100 \mathrm{ppm}$ to raise the supercooling point of field-collected, diapausing Colorado potato beetle adults by $2-3^{\circ} \mathrm{C}$. In northern potato-growing regions, diapausing beetles overwinter at soil depths of $10-30 \mathrm{~cm}$. At these depths the soil temperatures remain near $0^{\circ} \mathrm{C}$ when the soil surface is covered by an insulating layer of mulch or snow (Milner et al. 1992). Under such conditions, beetles rarely would be exposed to lethal winter temperatures. However, cultural manipulations designed to expose beetles to lethal low

Table 3. Supercooling points of Colorado potato beetles incubated at $4^{\circ} \mathrm{C}$ or $10^{\circ} \mathrm{C}$ untreated in sand or sand containing $P$. syringae

\begin{tabular}{lccccc}
\hline \hline \multirow{2}{*}{ Treatment } & \multicolumn{2}{c}{$4^{\circ} \mathrm{C}$} & & \multicolumn{2}{c}{$10^{\circ} \mathrm{C}$} \\
\cline { 2 - 3 } & Mean \pm SEM & $n$ & & Mean \pm SEM & $n$ \\
\hline Untreated & $-5.9 \pm 0.5 \mathrm{a}$ & 16 & & $-5.3 \pm 0.5 \mathrm{a}$ & 16 \\
$100 \mathrm{ppm}$ & $-3.3 \pm 0.4 \mathrm{a}$ & 14 & & $-5.8 \pm 0.3 \mathrm{~b}$ & 16 \\
$1000 \mathrm{ppm}$ & $-3.7 \pm 0.3 \mathrm{a}$ & 17 & & $-4.3 \pm 0.3 \mathrm{a}$ & 13 \\
\hline
\end{tabular}

Within a row, means followed by the same letter are not significantly different $(P>0.05)$. temperatures by removing insulating layers may cause a rapid decrease in soil temperatures of 5 to $7^{\circ} \mathrm{C}$ at $20-\mathrm{cm}$ depth (Kung et al. 1992, Milner et al. 1992). The cumulative freezing distributions (Fig. 1) clearly demonstrate the potential for icenucleating bacteria to increase mortality during such brief exposures to cold temperature shock. Beetles would be unlikely to experience lethal freezing at $-5^{\circ} \mathrm{C}$ unless exposed to ice-nucleating agents that would be expected to increase mortality to $80 \%$ based on the data in Fig. 1. Consequently, ice-nucleating active bacteria would significantly increase the effectiveness of field strategies designed to expose beetles to lethal low soil temperatures. The geographical range of areas where a sufficiently low soil temperature could be attained to increase mortality would be expanded considerably if the lethal temperature were raised to -2 or $-3^{\circ} \mathrm{C}$ using ice-nucleating microorganisms or agents. Similarly, the soil depth at which Colorado potato beetles would need to overwinter to avoid lethal exposure would be increased.

To integrate ice nucleation successfully into cultural strategies for increasing winter mortality, it will be necessary to design delivery systems that expose adult beetles to the icenucleating agent and preserve the agent's activity until critical low-temperature exposure occurs in midwinter.

\section{Acknowledgments}

We thank Cara Minks and Stacey Minges for their technical assistance. This research was supported by USDA North Central Region IPM Program, grant 9134103-5963, a Cooperative State Research Service (USDA) grant \#91-37302-6222 and 93-37302-9003, and Genencor International, Rochester, NY.

\section{References Cited}

Casagrande, R. A. 1987. The Colorado potato beetle: 125 years of mismanagement. Bull. Entomol. Soc. Am. 33: 142-150.

Fields, P. G. 1990. The cold-hardiness of Cryptolestes ferrugineus and the use of ice nucleationactive bacteria as a cold synergist, pp. 1183-1191. Proceedings, Fifth International Workshop Conference Stored-Product Protection, Bordeaux, France.

Fields, P. G. 1992. The control of stored-product insects and mites with extreme temperatures. J. Stored Prod. Res. 28: 89-118.

Ioannidis, P. I., E. J. Grafius \& M. E. Whalen. 1991. Patterns of insecticide resistance to azinphosmethyl, carbofuran, and permethrin in the Colorado potato beetle (Coleoptera: Chrysomelidae). J. Econ. Entomol. 84: 1417-1423.

Kung, K-J. S., M. Milner, J. A. Wyman, J. Feldman \& E. Nordheim. 1992. Survival of Colorado potato beetle (Coleoptera: Chrysomelidae) after exposure to subzero thermal shocks during diapause. J. Econ. Entomol. 85: 1695-1700. 
Lee, R. E. 1991. Principles of insect low temperature tolerance, pp. 17-46. In Insects at Low Temperature, R. E. Lee \& D. L. Denlinger [eds.], Chapman and Hall, New York.

Lee, R. E., J. M. Strong-Gunderson, M. R. Lee, K. S Grove \& T. J. Riga. 1991. Isolation of ice nucleating active bacteria from insects. J. Expt. Zool. 257: $124-127$.

Lee, R. E., J. M. Strong-Gunderson, M. R. Lee \& E. C. Davidson. 1992. Ice nucleating bacteria decrease the cold-hardiness of stored grain insects. J. Econ. Entomol. 85: 371-374.

Lee, R. E., M. R. Lee \& J. M. Strong-Gunderson. 1993. Insect cold-hardiness and ice nucleating active microorganisms including their potential use for biological control: a review. J. Insect Physiol. 39: $1-12$.
Milner, M., K-J. S. Kung, J. A. Wyman, J. Feldman \& E. Nordheim. 1992. Enhancing overwintering mortality of Colorado potato beetle (Coleoptera Chrysomelidae) by manipulating the temperature of its habitat. J. Econ. Entomol. 85: 1701-1708.

Snedecor, G. W. \& W. G. Cochran. 1982. Statistical methods, 7th ed. Iowa State University Press, Ames.

Strong-Gunderson, J. M., R. E. Lee, M. R. Lee \& T. J. Riga. 1990. Ingestion of ice nucleating active bacteria increases the supercooling point of the lady beetle Hippodamia convergens. J. Insect Physiol. 36: 153-157.

Received for publication 21 May 1993; accepted 8 November 1993. 